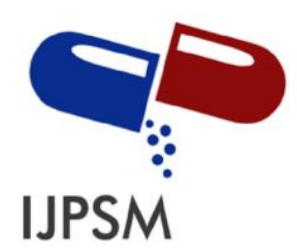

Oryza Sativa Fitriani et al, International Journal of Pharmaceutical Sciences and Medicine (IJPSM), Vol.6 Issue. 7, July- 2021, pg. 50-60

\title{
Phytochemical Screening and Antihypertensive Testing of Traditional Medicinal Ingredients of Indonesia
}

\author{
Oryza Sativa Fitriani; Suhatri; Harrizul Rivai* \\ Faculty of Pharmacy, Andalas University, Limau Manih Campus, Padang 25163, Indonesia \\ "Email: harrizul@yahoo.co.id
}

DOI: 10.47760/ijpsm.2021.v06i07.005

\begin{abstract}
Traditional medicinal ingredients originating from the Province of East Kalimantan (Indonesia) with the composition of meniran leaves (Phyllanthus niruri L.), cat whiskers leaves (Orthosiphon aristatus), ceplukan leaves (Physalis minima L.), and lempuyang emprit rhizome (Zingiberis amaricana Bl.) are used to help lower blood pressure by the local community. This study aimed to analyze the content of chemical compounds, determine the levels of chemical compounds, and the antihypertensive effect of these traditional medicinal ingredients. This traditional medicinal herb is made into a fine powder and then brewed with boiling water. Phytochemical screening and determination of levels of phytochemical compounds were carried out on these traditional medicinal ingredients. Testing the antihypertensive effect of these traditional medicinal ingredients was carried out on white male rats. The results of the qualitative analysis showed that the chemical compounds contained in the traditional medicinal ingredients were flavonoids, phenols, tannins, and carbohydrates. Quantitative analysis of the traditional medicinal ingredients showed that the content of flavonoid compounds was $0.6375 \%$, phenolic compounds were $3.2412 \%$, and tannin compounds were $0.6593 \%$. Testing the antihypertensive effect of this traditional medicinal herb on rats can reduce systolic, diastolic, and arterial blood pressure. The conclusion is that this traditional medicinal herb contains phytochemical compounds that can help lower blood pressure in rats.
\end{abstract}

Keywords: traditional medicinal ingredients, phytochemical screening, quantitative analysis, antihypertensive

\section{Introduction}

High blood pressure or hypertension is generally defined by persistently elevated arterial blood pressure, where the systolic blood pressure is more significant than $140 \mathrm{mmHg}$, and the diastolic blood pressure is greater than $90 \mathrm{mmHg}$ [1]. Hypertension is a heterogeneous disease that can be caused by a specific cause (secondary hypertension) or an unknown pathophysiological mechanism (primary or essential hypertension) [2]. Hypertension over a long period can cause stroke, heart disease, and kidney damage if not detected early and get treatment [3]. Therefore, preventive and curative measures must be taken. Chemical drugs used to treat hypertension usually have side effects, so traditional medicine as a source of natural and healthy medicines is critical [4].

Since ancient times, Indonesian people have also used traditional medicine to maintain health, prevent disease, and take care of health. One of the traditional treatments is traditional medicinal herbs which are an option to help lower high blood pressure. These traditional medicinal ingredients can come from plants, animals, and minerals, but generally, those often used come from plants. Traditional medicinal ingredients are one or more types of plants that are traditionally processed with other additives that are inert/neutral in the form of plant 


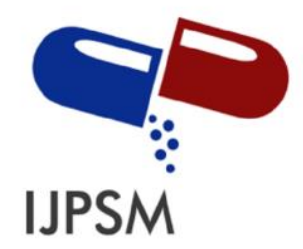

Oryza Sativa Fitriani et al, International Journal of Pharmaceutical Sciences and Medicine (IJPSM), Vol.6 Issue. 7, July- 2021, pg. 50-60

ISSN: 2519-9889

Impact Factor: 3.426

materials, animal materials, mineral materials, preparations of extract (galenic), or a mixture of these materials which have been used for generations for treatment. They can be applied by the norms prevailing in society. Based on a book published by the Food and Drug Supervisory Agency of the Republic of Indonesia (2011), one of the traditional treatments used to reduce high blood pressure is a traditional medicinal herb with a composition consisting of meniran leaves, cat whiskers leaves, ceplukan leaves, and lempuyang emprit rhizome. This traditional medicinal herb comes from the Province of East Kalimantan (Indonesia). There has been no testing on traditional medicinal ingredients from the literature search to reduce high blood pressure. Therefore, the authors wanted to examine this traditional medicinal herb originating from East Kalimantan (Indonesia) province to prove that these ingredients can reduce high blood pressure in rats.

\section{Materials and methods}

\subsection{Tools and materials}

The tools used in this study were Triple Beam Balance (OHAUS), Analytical Scales (Precisa), and CODA® Non-Invasive Blood Pressure (Kent Scientific Corporation). The materials used in this study were fresh meniran leaves (Phyllanthus niruri), fresh cat whiskers (Orthosiphon aristatus), fresh ceplukan leaves (Physalis minima L) and lempuyang emprit rhizome (Zingiber amaricana), animal feed pellets Hi-Pro-Vite 511 (PT Charoen Indonesia), Prednisone $5 \mathrm{mg}$ tablets (PT Triman), Folin-Ciocalteu (Merck), gallic acid (Merck), aluminum chloride (Bratachem), gallic acid (Merck), and catechins (Mark Herb).

\subsection{Procedure}

\subsubsection{Sampling}

The samples used in this study were fresh leaves from meniran plants (Phyllanthus niruri L), cat's whiskers (Orthosiphon aristatus), ceplukan (Physalis minima L), and lempuyang emprit rhizome (Zingiberis amaricana Bl) taken at Kubu Dalam Parak Karakah Village, Padang East and in Nagari Sungai Aro, Sangir District, Solok-South Regency, West Sumatra.

\subsubsection{Sample Preparation}

$80 \mathrm{~g}$ of meniran leaves, $80 \mathrm{~g}$ of cat whiskers leaves, $80 \mathrm{~g}$ of ceplukan leaves, and lempuyang emprit rhizome with a length of $\pm 8 \mathrm{~cm}$ were cut into pieces first. Then all the ingredients were dried in the sun to dry. Then grind it in a blender. After smooth, taken as much as one tablespoon $(4 \mathrm{~g})$ of fine powder brewed with half a glass $(100 \mathrm{~mL})$ boiling water. Let stand for 5-10 minutes, then strain.

\subsubsection{Phytochemical Test}

The phytochemical test was carried out to determine primary and secondary metabolites contained in traditional medicinal herbs. The primary metabolites tested were carbohydrates, amino acids, proteins, oils, and fats, while the secondary metabolites tested were alkaloids, phenols, flavonoids, saponins, steroids, terpenoids, saponins, tannins, and glycosides.

\subsubsection{Determination of flavonoid levels}

Test solution: as much as $2 \mathrm{~mL}$ of the test preparation is put into a measuring flask, add $10 \mathrm{~mL}$ of ethanol $\mathrm{P}$ to the limit mark, stir for 30 minutes with a magnetic stirrer. Then filter into a $10 \mathrm{~mL}$ volumetric flask, add ethanol P through a filter until the mark. Comparison solution: weigh approximately $10 \mathrm{mg}$ of rutin, put into a $25 \mathrm{~mL}$ volumetric flask, dissolve and add ethanol $\mathrm{P}$ to volume. Make a series of dilutions of the comparison solution with levels of $140,120,100,80$, and $60 \mathrm{~g} / \mathrm{mL}$, respectively.

Procedure: pipette separately the test solution and $1 \mathrm{~mL}$ of each series of reference solutions into a suitable container, add each $1.5 \mathrm{~mL}$ of ethanol $\mathrm{P}, 0.1 \mathrm{~mL}$ of $10 \%$ aluminum chloride, $0.1 \mathrm{~mL}$ of sodium acetate $1 \mathrm{M}$, and $2.8 \mathrm{~mL}$ of water. Shake and let stand for 30 minutes at room temperature. Measure the absorption at a maximum absorption wavelength of approximately $411 \mathrm{~nm}$ [5]. 


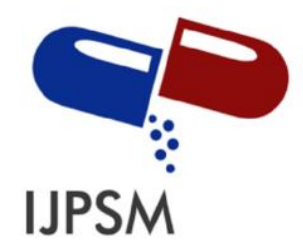

Oryza Sativa Fitriani et al, International Journal of Pharmaceutical Sciences and Medicine (IJPSM), Vol.6 Issue. 7, July- 2021, pg. 50-60

ISSN: 2519-9889

Impact Factor: 3.426

\subsubsection{Determination of Phenol Level}

Determination of phenolic content was carried out using the Folin-Ciocalteau method. Test solution: $2 \mathrm{~mL}$ of the test preparation was put into a $50 \mathrm{~mL}$ volumetric flask and added methanol $\mathrm{P}$ to the limit mark. Stir for 30 minutes with a magnetic stirrer. Strain into a $50 \mathrm{~mL}$ volumetric flask, add methanol P through a filter to mark. Comparison solution: weigh approximately $10 \mathrm{mg}$ of gallic acid carefully, put into a $25 \mathrm{~mL}$ volumetric flask, dissolve with methanol P, add methanol P to volume. Make a series of comparison solution diluents with levels of 70,60,50,40, and $30 \mathrm{ppm}$, respectively. Procedure: Separately pipette $1 \mathrm{~mL}$ of the test solution and $1 \mathrm{~mL}$ of each series of reference solutions into the appropriate container. Add $5 \mathrm{~mL}$ of Folin-Ciocalteu LP $(7.5 \%$ in water). Let stand 8 minutes, then add $4 \mathrm{~mL}$ of $1 \% \mathrm{NaOH}$, incubate for 1 hour. Measure the absorption of each solution at a maximum absorption wavelength of approximately $761 \mathrm{~nm}[5]$.

\subsubsection{Determination of Tannin Levels}

Test solution: $1 \mathrm{~mL}$ of the test preparation is put into a $50 \mathrm{~mL}$ volumetric flask, add ethyl acetate $\mathrm{P}$ to the limit mark. Sonication for 5 minutes. Comparison solution: Catechin as much as $10 \mathrm{mg}$ was put into a $10 \mathrm{~mL}$ volumetric flask. Dissolve with ethyl acetate P, sonicate for 5 minutes. Then pipette $2 \mathrm{~mL}$ of the solution, put it into a $100 \mathrm{~mL}$ glass-stoppered Erlenmeyer flask, add $50 \mathrm{~mL}$ of ethyl acetate $\mathrm{P}$, sonicate again for 5 minutes. Procedure: measure the absorption of the test solution, the reference solution, and the blank ethyl acetate $\mathrm{P}$ solution at a wavelength of $280 \mathrm{~nm}$. Calculate \% of catechins in the test solution at a wavelength of $280 \mathrm{~nm}$ [5].

\subsubsection{Preparation of Antihypertensive Test Animals}

The animals used were white male rats aged 2.5-3 months with an average body weight of 250-300 grams as many as 15 rats. Experimental animals were acclimatized for seven days to uniform the way of life and food of the experimental animals used in the study to obtain experimental animals with health conditions. The animals were weighed, and their behavior was observed. During rearing, the weight of the animals was weighed, and their behavior was observed. Animals are declared suitable for use if their behavior is normal and do not experience more than $10 \%$ [6].

\subsubsection{Dosage Planning and Testing of Antihypertensive Effectiveness}

Male white rats were induced with $8 \% \mathrm{NaCl}$ and prednisone $5 \mathrm{mg} / \mathrm{kg}$ BW orally for 14 days. Rats were categorized as hypertensive if their blood pressure reached $140 / 90 \mathrm{mmHg}$. The doses used for testing the effectiveness of antihypertensives in traditional medicinal herbs are $36 \mathrm{mg} / 200 \mathrm{~g} \mathrm{BW}, 72 \mathrm{mg} / 200 \mathrm{~g} \mathrm{BW}$, and $144 \mathrm{mg} / 200 \mathrm{~g} \mathrm{BW}$. The test preparation was given orally to hypertensive rats for 21 days. Systolic, diastolic, arterial blood pressure was measured on days 7,14 , and 21 . The experimental animals were divided into five groups, including group 1 negative control, group 2 positive control, dose group 1, 2, and 3 given traditional medicinal herbs with doses 1,2 and 3 respectively $36 \mathrm{mg} / 200 \mathrm{~g} \mathrm{BW}, 72 \mathrm{mg} / 200 \mathrm{~g} \mathrm{BW}$ and $144 \mathrm{mg} / 200 \mathrm{~g} \mathrm{BW}$.

\subsubsection{Blood Pressure Measurement}

The mice were conditioned in the holder for 10-15 minutes. Measurements of rats were warmed to $37{ }^{\circ} \mathrm{C}$ on a warming pad to measure blood pressure quickly and consistently. Then the rat's tail was fitted with a rubber occlusion cuff and then followed by a VPR cuff as a detector, the cuff pulse would automatically expand, pressing the rat's tail which was flowing with blood, and the pulse of blood flow would be detected [7]. 


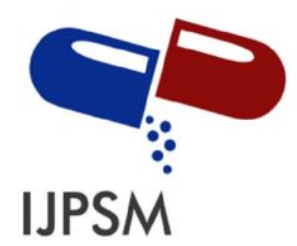

Oryza Sativa Fitriani et al, International Journal of Pharmaceutical Sciences and Medicine (IJPSM), Vol.6 Issue. 7, July- 2021, pg. 50-60

ISSN: 2519-9889

Impact Factor: 3.426

\section{Results and Discussion}

\subsection{Qualitative analysis}

Phytochemical test results from traditional medicinal ingredients as listed in Table 1 are as follows:

Table 1: Phytochemical test results of traditional medicinal ingredients

\begin{tabular}{|c|c|c|c|}
\hline $\begin{array}{c}\text { Chemical } \\
\text { Parameter }\end{array}$ & Test & Observation & Conclusion \\
\hline \multirow{2}{*}{ Flavonoids } & Cyanidine test & brick red & + \\
\cline { 2 - 4 } & $\begin{array}{c}\text { Ammonium } \\
\text { Test }\end{array}$ & Yellow & + \\
\hline Phenolic & $\mathrm{FeCl}_{3}$ & Blackish green & + \\
\hline \multirow{2}{*}{ Tannins } & $\mathrm{FeCl}_{3}$ & Blackish green & + \\
\cline { 2 - 4 } & Lead Acetate & White precipitate & + \\
\hline \multirow{2}{*}{ Carbohydrate } & Molisch test & $\begin{array}{c}\text { Formation of a purple ring at the } \\
\text { liquid boundary }\end{array}$ & + \\
\cline { 2 - 4 } & Fehling test & Formation of a brick-red precipitate & + \\
\hline
\end{tabular}

\subsection{Quantitative analysis}

\subsubsection{Flavonoids}

Determination of total flavonoid content of traditional medicinal ingredients was carried out using the colorimetric method. The principle of the colorimetric method is the formation of a stable acid complex by aluminum chloride with a keto group on the C-4 atom and a hydroxyl group on the C-3 or C-5 atom, which is neighboring the flavone and flavanone groups. Where this reaction will give a stable yellow color, and the absorbance can be measured. Aluminum chloride will form stable acid complexes with orthodihydroxy groups on the A- or B- rings of flavonoids. The regression equation obtained in the test is $\mathrm{y}=0.0065 \mathrm{x}-0.1207$ with a correlation coefficient of 0.9992 (Figure 1). Based on the results obtained, the total flavonoid content in traditional medicinal ingredients is $0.6375 \%$.

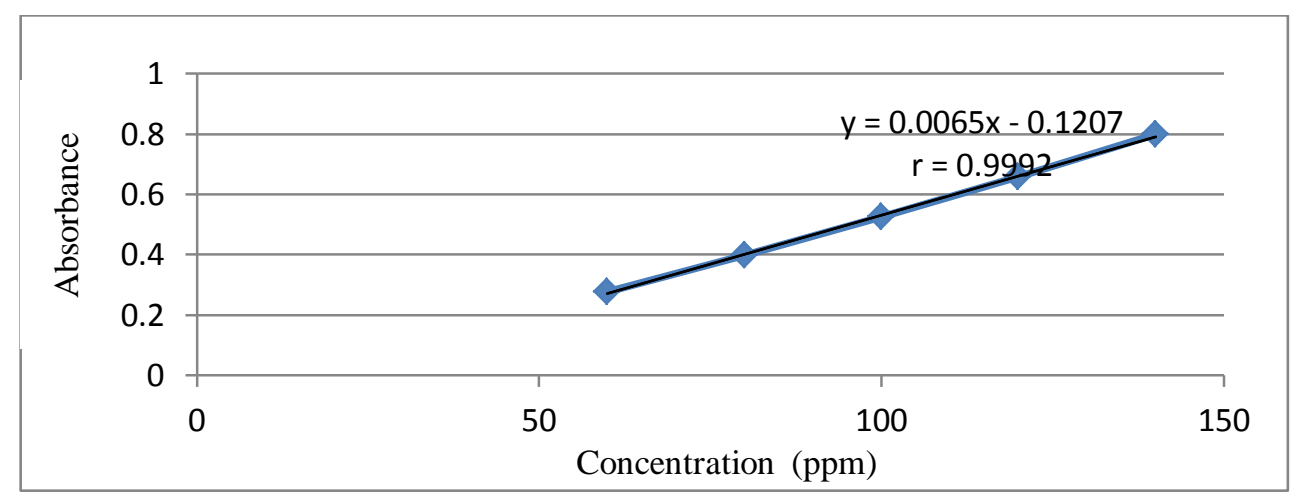

Figure 1. Rutin-aluminum chloride calibration curve at a wavelength of $411 \mathrm{~nm}$

\subsubsection{Phenol}

Determination of total phenol content was carried out using the Folin-Ciocalteau method, which is the most commonly used method to determine total phenol content. The regression equation obtained in the test is $\mathrm{y}=$ 


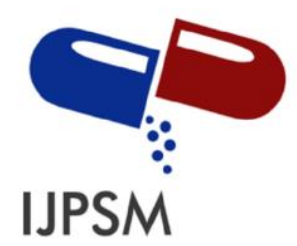

Oryza Sativa Fitriani et al, International Journal of Pharmaceutical Sciences and Medicine (IJPSM), Vol.6 Issue. 7, July- 2021, pg. 50-60

ISSN: 2519-9889

Impact Factor: 3.426

$0.01 \mathrm{x}+0.0504$ with a correlation coefficient of 0.9945 (Figure 2). Based on the results that have been obtained, the total phenol content in traditional medicinal ingredients is $3.2412 \%$.

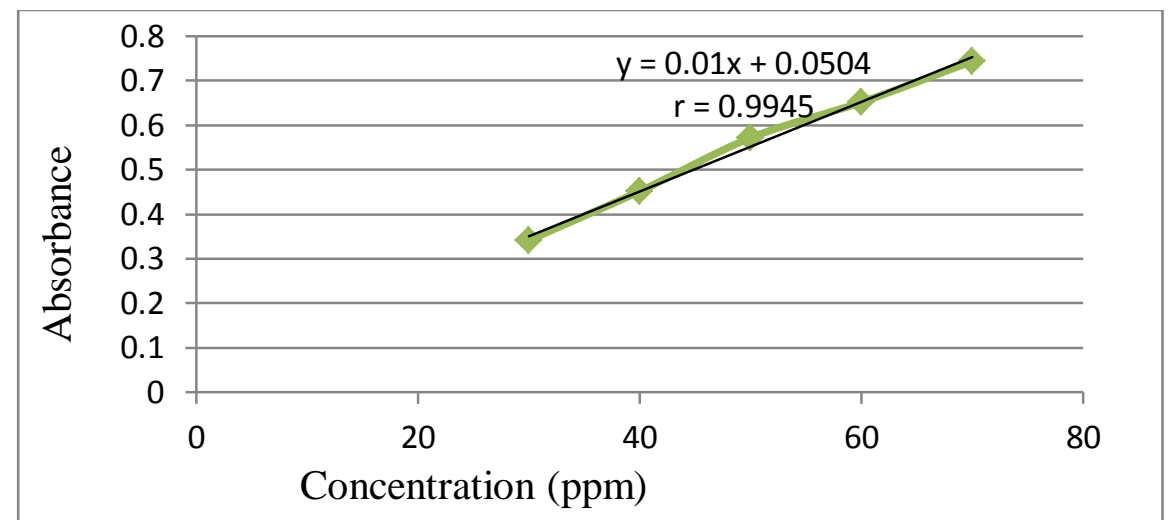

Figure 2. Gallic acid-Folin Ciocalteau calibration curve at a concentration of $60 \mathrm{ppm}$ at a wavelength of $761 \mathrm{~nm}$

\subsubsection{Tannins}

Total tannin content was determined using an ultraviolet-visible spectrophotometer with catechins as a standard solution as a comparison. Determination of the maximum wavelength of catechins is $280 \mathrm{~nm}$ with an absorbance of 0.676. Based on the results of research conducted on traditional medicinal ingredients obtained tannin levels of $0.6593 \%$.

\subsection{Antihypertensive}

All data on systolic blood pressure, diastolic blood pressure, and mean arterial pressure of the test animals were generally distributed after being analyzed by Shapiro-Wilk $(\mathrm{P}>0.05)$. Systolic blood pressure, diastolic, and mean arterial pressure of rats were significantly affected $(\mathrm{P}<0.05)$ dose, duration of administration, and interaction of dose and duration of administration of traditional medicinal herbs $(\mathrm{P}<0.05)$. The results of the effect of decreasing systolic blood pressure are shown in Table 2.

Table 2: The results of the effect of traditional medicinal herbs on the average systolic blood pressure of white male rats

\begin{tabular}{|l|l|l|l|l|l|l|}
\hline \multirow{2}{*}{$\begin{array}{c}\text { Treatment } \\
\text { group }\end{array}$} & \multicolumn{7}{|c|}{ Decrease in mean systolic blood pressure (mmH) on day } & \multicolumn{2}{l|}{ Average \pm SD } \\
\cline { 2 - 7 } & $\begin{array}{l}\text { Before } \\
\text { induction }\end{array}$ & After induction & Day 7 & Day 14 & Day 21 & \\
\hline $\begin{array}{l}\text { Negative } \\
\text { control }\end{array}$ & $114.67 \pm 8.386$ & $113.33 \pm 10.408$ & $116 \pm 9.539$ & $\begin{array}{l}115.33 \\
\pm \\
13.013\end{array}$ & $\begin{array}{l}116 \pm \pm \\
13.000\end{array}$ & $115.07 \pm 9.377^{\mathrm{a}}$ \\
\hline $\begin{array}{l}\text { positive } \\
\text { control }\end{array}$ & $115.67 \pm 10.599$ & $154.33 \pm 11.676$ & $157 \pm 6.245$ & $\begin{array}{l}160 \pm \\
15.588\end{array}$ & $\begin{array}{l}183.67 \pm \\
23.861\end{array}$ & $154.13 \pm 25.890^{\mathrm{d}}$ \\
\hline dose 1 & $120 \pm 6.928$ & $156.67 \pm 5,686$ & $145.67 \pm 11.150$ & $\begin{array}{l}135.67 \\
\pm 7.638\end{array}$ & $\begin{array}{l}128 \pm \\
7.211\end{array}$ & $137.20 \pm 14.953^{\mathrm{b}}$ \\
\hline dose 2 & $110.67 \pm 23.629$ & $153.33 \pm 9.292$ & $153.33 \pm 9.292$ & $\begin{array}{l}129.33 \\
\pm 9.292\end{array}$ & $\begin{array}{l}123.33 \pm \\
5.508\end{array}$ & $131.80 \pm 18.770^{\mathrm{b}}$ \\
\hline
\end{tabular}




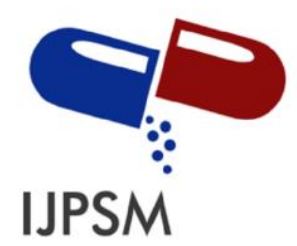

Oryza Sativa Fitriani et al, International Journal of Pharmaceutical Sciences and Medicine (IJPSM), Vol.6 Issue. 7, July- 2021, pg. 50-60

ISSN: 2519-9889

Impact Factor: 3.426

\begin{tabular}{|l|l|l|l|l|l|l|}
\hline dose 3 & & & & & & \\
& $113.33 \pm 10,017$ & $155.33 \pm 5.508$ & $137.67 \pm 11.015$ & $\begin{array}{l}129 \\
7.211\end{array}$ & $\begin{array}{l}108.33 \pm \\
12.858\end{array}$ & $128.73 \pm 19.385^{\mathrm{b}}$ \\
\hline Average \pm SD & $114.87 \pm 11.710$ & $146.60 \pm 18.814$ & $139.73 \pm 16.007$ & $\begin{array}{l}133.87 \\
\pm \\
17.808\end{array}$ & $\begin{array}{l}131.87 \pm \\
30.121\end{array}$ & \\
\hline
\end{tabular}

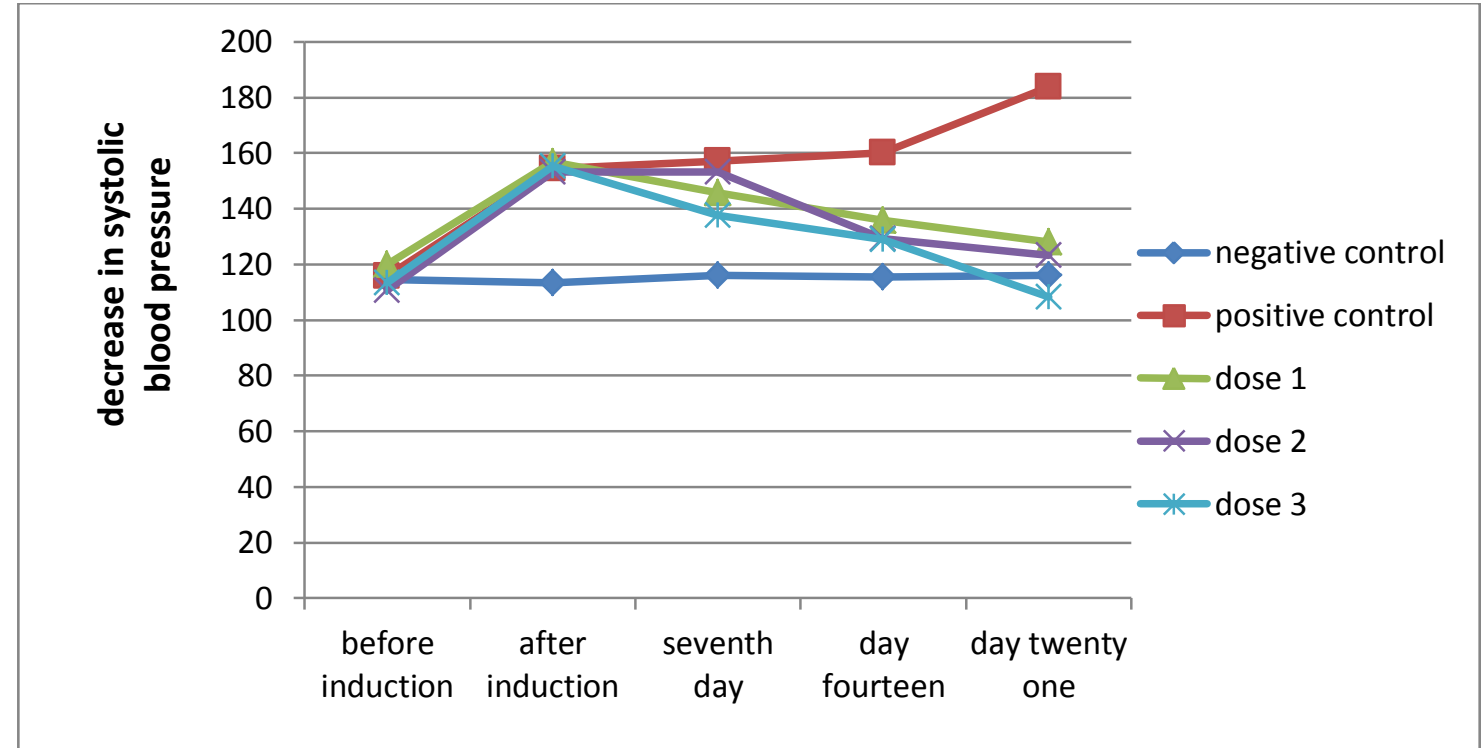

Figure 3: Effect of dose and duration of administration of traditional medicinal herbs on decreasing mean systolic blood pressure of white male rats

It can be seen in Table 2 and the graph in Figure 3 that after being induced by prednisone and $\mathrm{NaCl}$, the positive control group, dose 1, dose 2, and dose 3, increased systolic blood pressure. After being given traditional medicinal herbs on days 7,14 , and 21 , there was a decrease compared to the positive control.

The following results obtained the effect of decreasing diastolic blood pressure, as shown in Table 3.

Table 3. The effect of traditional medicinal herbs on the average diastolic blood pressure of white male rats

\begin{tabular}{|c|c|c|c|c|c|c|}
\hline \multirow{2}{*}{$\begin{array}{l}\text { Treatment } \\
\text { group }\end{array}$} & \multicolumn{5}{|c|}{ Decrease in mean diastolic blood pressure $(\mathrm{mmHg})$ on day } & \multirow[b]{2}{*}{ Average \pm SD } \\
\hline & $\begin{array}{l}\text { Before } \\
\text { induction }\end{array}$ & $\begin{array}{l}\text { After } \\
\text { induction }\end{array}$ & day 7 & day 14 & day 21 & \\
\hline $\begin{array}{l}\text { Negative } \\
\text { control }\end{array}$ & $\begin{array}{l}89.67 \pm \\
10.066\end{array}$ & $81 \pm 7.937$ & $\begin{array}{l}84 \pm \\
11.790 \\
\end{array}$ & $\begin{array}{l}84.67 \pm \\
11.150 \\
\end{array}$ & $\begin{array}{l}82.33 \pm \\
13.650 \\
\end{array}$ & $84.33 \pm 9.854^{\mathrm{a}}$ \\
\hline $\begin{array}{l}\text { positive } \\
\text { control }\end{array}$ & $77.67 \pm 5.508$ & $\begin{array}{l}131.33 \pm \\
14.012\end{array}$ & $\begin{array}{l}130 \pm \\
6.557\end{array}$ & $\begin{array}{l}134 \pm \\
10.440\end{array}$ & $\begin{array}{l}146.33 \pm \\
14.224\end{array}$ & $123.87 \pm 26.278^{c}$ \\
\hline dose 1 & $86 \pm 8.888$ & $\begin{array}{l}120 \pm \\
7.550\end{array}$ & $\begin{array}{l}109 \pm \\
6.083\end{array}$ & $\begin{array}{l}108.67 \pm \\
13.429\end{array}$ & $\begin{array}{l}91 \pm \\
5.292\end{array}$ & $102.93 \pm 14.959^{b}$ \\
\hline dose 2 & $\begin{array}{l}84.67 \pm \\
14.640\end{array}$ & $\begin{array}{l}120.33 \pm \\
13.051\end{array}$ & $\begin{array}{l}105.33 \pm \\
11.372\end{array}$ & $96 \pm 3.606$ & $\begin{array}{l}93.33 \pm \\
7.371\end{array}$ & $99.93 \pm 15.526^{\mathrm{b}}$ \\
\hline
\end{tabular}




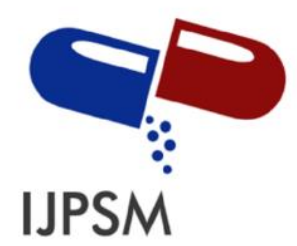

Oryza Sativa Fitriani et al, International Journal of Pharmaceutical Sciences and Medicine (IJPSM), Vol.6 Issue. 7, July- 2021, pg. 50-60

ISSN: 2519-9889 Impact Factor: 3.426

\begin{tabular}{|l|l|l|l|l|l|l|}
\hline dose 3 & $82.67 \pm$ & $132 \pm$ & $112.33 \pm$ & $101.33 \pm$ & $81 \pm$ & \multirow{2}{*}{$101.87 \pm 21.088^{\mathrm{b}}$} \\
& 10.017 & 2.646 & 2.887 & 9.452 & 13.229 & \\
\hline Average \pm & \multirow{2}{*}{$84.13 \pm 9.583^{\mathrm{p}}$} & $116.93 \pm$ & $108.13 \pm$ & $104.93 \pm$ & $98.80 \pm$ & \\
SD & $21.090^{\mathrm{s}}$ & $16.847^{\mathrm{r}}$ & $19.122^{\mathrm{q}}$ & $26.868^{\mathrm{q}}$ & \\
\hline
\end{tabular}

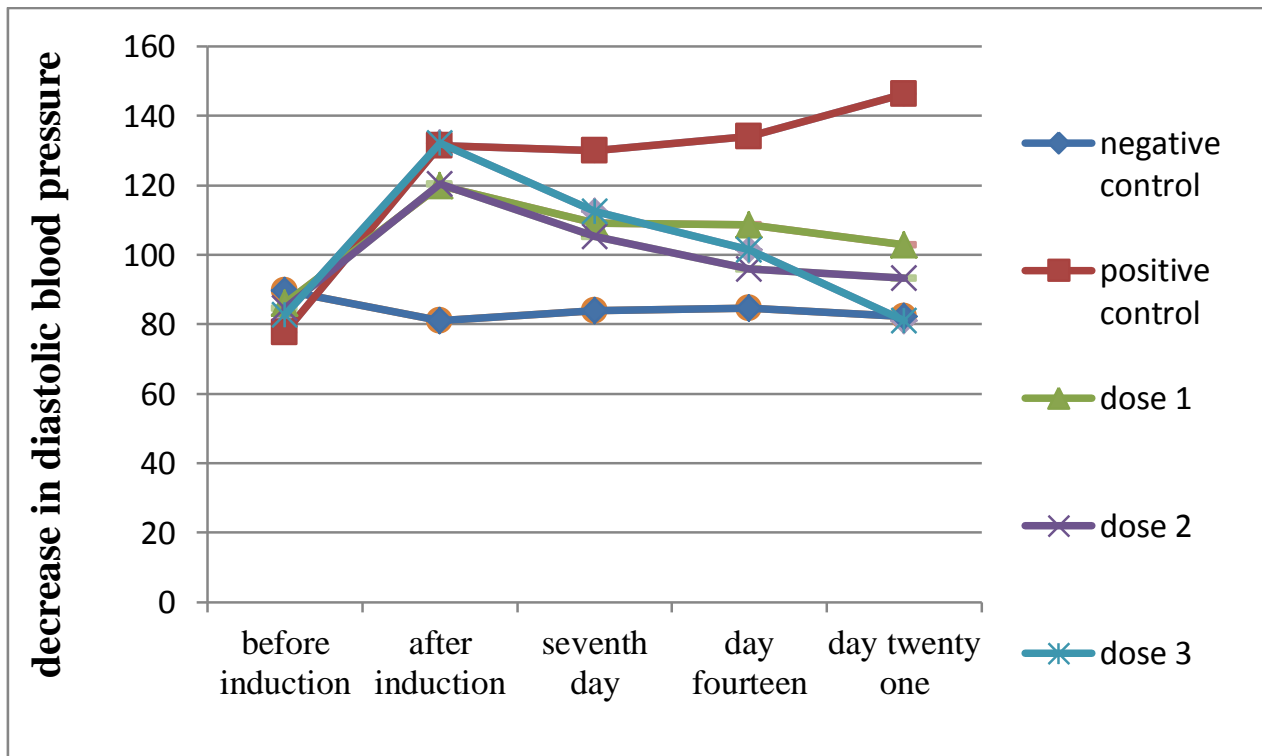

Figure 4: Effect of dose and duration of administration of traditional medicinal herbs on decreasing diastolic blood pressure on average male white rat

It can be seen in Table 3, and the graph in Figure 4 positive control group, dose 1, dose 2, and dose 3 after prednisone and $\mathrm{NaCl}$ increased diastolic blood pressure. After being given traditional medicinal herbs on days 7,14 , and 21 , there was a decrease compared to the positive control.

The following results obtained the effect of decreasing arterial blood pressure, as shown in Table 4.

Table 4: The effect of traditional medicinal herbs on the average arterial pressure of white male rats

\begin{tabular}{|c|c|c|c|c|c|c|}
\hline \multirow{2}{*}{$\begin{array}{l}\text { Treatment } \\
\text { group }\end{array}$} & \multicolumn{5}{|c|}{ Decrease in mean arterial pressure $(\mathrm{mmHg})$ on day } & \multirow{2}{*}{$\begin{array}{c}\text { Average } \pm \\
\text { SD }\end{array}$} \\
\hline & $\begin{array}{l}\text { Before } \\
\text { induction }\end{array}$ & $\begin{array}{l}\text { After } \\
\text { induction }\end{array}$ & Day 7 & Day 14 & Day 21 & \\
\hline $\begin{array}{l}\text { Negative } \\
\text { control }\end{array}$ & $98 \pm 9.165$ & $91 \pm 8.660$ & $\begin{array}{l}95 \pm \\
11.533\end{array}$ & $\begin{array}{l}94.67 \pm \\
11,372\end{array}$ & $\begin{array}{l}96 \pm \\
17.578\end{array}$ & $\begin{array}{l}94.93 \pm \\
10.484^{\mathrm{a}}\end{array}$ \\
\hline $\begin{array}{l}\text { positive } \\
\text { control }\end{array}$ & $\begin{array}{l}90.33 \pm \\
6.506\end{array}$ & $\begin{array}{l}138.67 \pm \\
3.055\end{array}$ & $\begin{array}{l}131.33 \pm \\
7.234\end{array}$ & $\begin{array}{l}158.67 \pm \\
17.098\end{array}$ & $\begin{array}{l}158.67 \pm \\
17.098\end{array}$ & $\begin{array}{l}131.53 \pm \\
24.945^{\mathrm{c}}\end{array}$ \\
\hline dose 1 & $97 \pm 7.550$ & $\begin{array}{l}131.67 \pm \\
3.055\end{array}$ & $\begin{array}{l}120.67 \pm \\
2.887\end{array}$ & $\begin{array}{l}117.67 \pm \\
12.423\end{array}$ & $\begin{array}{l}104 \pm \\
5.568\end{array}$ & $\begin{array}{l}114.20 \pm \\
14.133^{\mathrm{b}}\end{array}$ \\
\hline dose 2 & $\begin{array}{l}94.67 \pm \\
22.591 \\
\end{array}$ & $131 \pm 10$ & $\begin{array}{l}117.33 \pm \\
9.018\end{array}$ & $\begin{array}{l}106.67 \pm \\
5.508\end{array}$ & $\begin{array}{l}107.33 \pm \\
11.590\end{array}$ & $\begin{array}{l}111.40 \pm \\
16.749^{\mathrm{b}}\end{array}$ \\
\hline
\end{tabular}




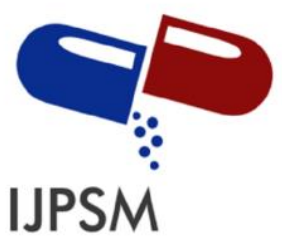

Oryza Sativa Fitriani et al, International Journal of Pharmaceutical Sciences and Medicine (IJPSM), Vol.6 Issue. 7, July- 2021, pg. 50-60

ISSN: 2519-9889

Impact Factor: 3.426

\begin{tabular}{|l|l|l|l|l|l|l|}
\hline dose 3 & $93 \pm 10$ & $\begin{array}{l}139.33 \pm \\
2.887\end{array}$ & $122 \pm 3$ & $110 \pm 7$ & $\begin{array}{l}91 \pm 1 \\
5.716\end{array}$ & $\begin{array}{l}111.07 \pm \\
20.306^{\mathrm{b}}\end{array}$ \\
\hline & & & & & \\
& & $126.33 \pm$ & $118.73 \pm$ & $111.87 \pm$ \\
Average \pm SD & $\begin{array}{l}94.60 \pm \\
11.025\end{array}$ & 19.924 & 15.613 & 14.613 & $\begin{array}{l}11.40 \pm \\
27.908\end{array}$ & \\
& & & & & & \\
\hline
\end{tabular}

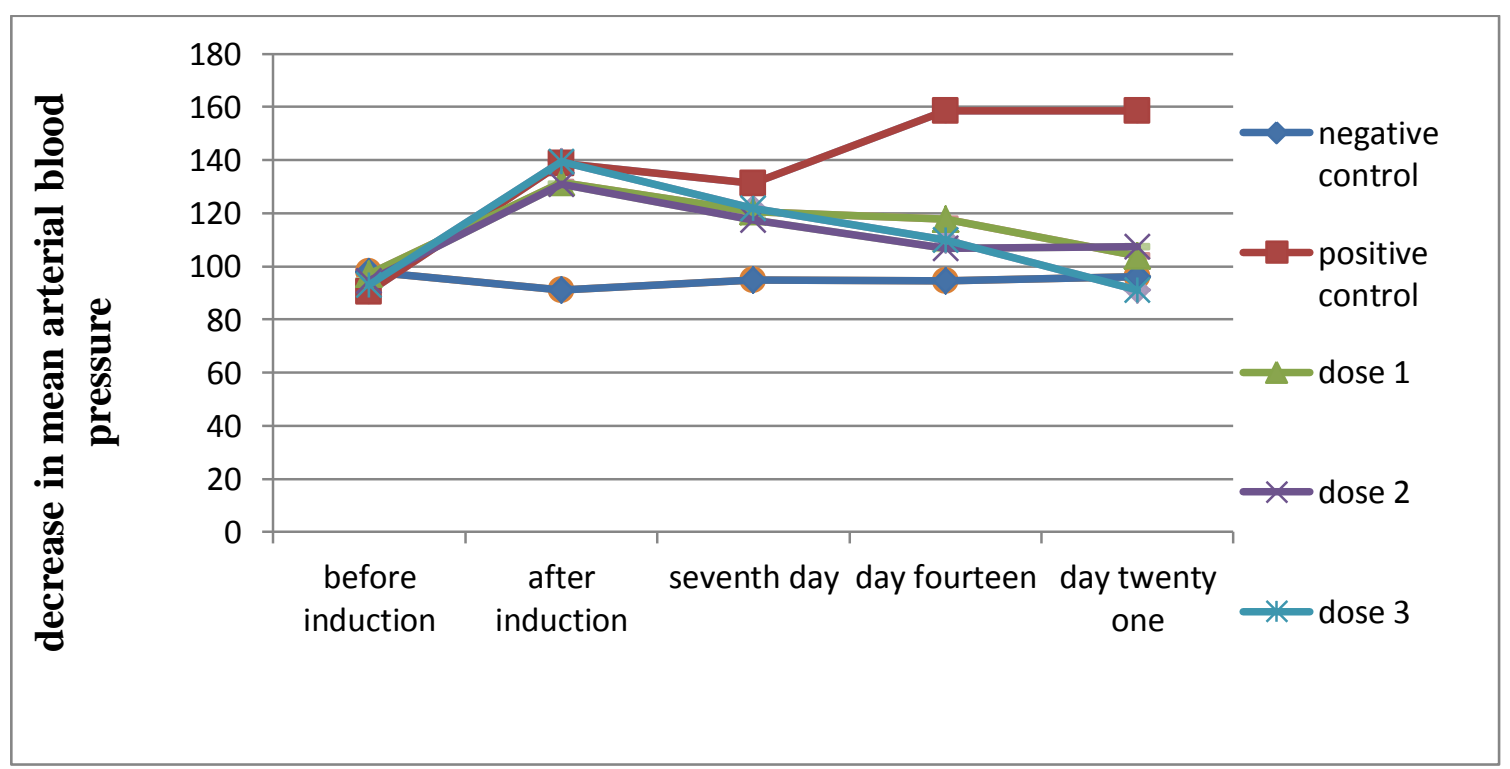

Figure 5: Effect of dose and duration of administration of traditional medicinal herbs on decreasing mean arterial pressure of white male rats

It can be seen in Table 4, and the graph in Figure 5 positive control group, dose 1, dose 2, and dose 3 after prednisone and $\mathrm{NaCl}$ induced mean arterial pressure increased. After being given traditional medicinal herbs on days 7,14 , and 21 , there was a decrease compared to positive controls whose mean arterial pressure remained high.

Based on the two-way ANOVA test results, there was a significant effect $(\mathrm{P}<0.05)$ with the administration of different doses on the decrease in systolic, diastolic, and mean arterial blood pressure. After continued with Duncan's test, the effect of the three doses was not significantly different but significantly different from negative control (normal animals) and positive control. It proves that there is an effect of traditional medicinal herbs that can lower systolic blood pressure, diastolic, and mean arterial pressure. However, it has not given optimal results because after being continued with the Duncan method. The results of the three variations in dosage are different with negative controls (normal animals) $\mathrm{P}>0.05$, meaning that the effect of decreasing systolic, diastolic, and mean arterial blood pressure is not good because it is not the same as the control negative (normal animal).

The results of the two-way ANOVA test for the duration of traditional medicinal herbs also gave a significant effect $(\mathrm{P}<0.05)$ on the decrease in systolic, diastolic, and mean arterial blood pressure. After being continued with the Bonferroni test, it turned out that the rats before induction (normal animals) were significantly different from the rats after induction (positive control), meaning that there was an increase in blood pressure after being induced by $\mathrm{NaCl}$ and prednisone. In the group of rats after being given traditional medicinal herbs, it turned out that administration for seven days did not have the effect of reducing systolic, diastolic, and mean 


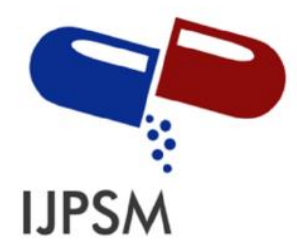

Oryza Sativa Fitriani et al, International Journal of Pharmaceutical Sciences and Medicine (IJPSM), Vol.6 Issue. 7, July- 2021, pg. 50-60

ISSN: 2519-9889

Impact Factor: 3.426

arterial blood pressure because the sig value was $\mathrm{P}>0.05$, meaning that it was not significantly different from the rats after induction (positive control). While the duration of administration for 14 days was not significantly different from the duration of administration for seven days and 21 days because the Sig value was $P>0.05$, meaning that there was no difference between days 7, 14, and 21 on the decrease in systolic, diastolic and mean arterial blood pressure. However, it was significantly different from rats after induction (positive control), meaning that there was an influence from traditional medicinal ingredients. However, it was also significantly different from rats before induction (normal animals), meaning that the effect/influence of traditional medicinal herbs on systolic, diastolic and mean arterial blood pressure was not good/not maximal. The decrease was seen after the administration of traditional medicinal herbs for 14 days and 21 days.

This study used a combination of $8 \% \mathrm{NaCl}$ and prednisone as an inducer of hypertension because $8 \% \mathrm{NaCl}$ can cause an increase in osmotic pressure in the blood. It stimulates the release of antidiuretic hormone (ADH) and causes thirst, which encourages us to drink. It increases the volume of blood in the body. At the same time, prednisone can cause the retention of $\mathrm{Na}$ and water. It will reduce the amount of salt and water excreted in the urine and consequently increase blood volume. Increasing levels of $\mathrm{Na}$ in the blood causes the smooth muscle of blood vessels to become sensitive to adrenaline and causes vasoconstriction. So that the combination of $\mathrm{NaCl}$ and prednisone increases blood volume, which means the heart has to pump blood more vigorously so that cardiac output increases and vasoconstriction occurs, which consequently causes an increase in blood pressure [8].

It is suspected that traditional medicinal herbs can reduce high blood pressure due to the active compounds of flavonoids, phenols, and tannins. Flavonoids will affect Angiotensin-Converting Enzym (ACE) performance by preventing angiotensin II formation from angiotensin I. So that vasodilation will occur if angiotensin II is not formed due to inhibition of ACE performance so that peripheral resistance and blood pressure will decrease $\mathrm{e}^{[9]}$. The antioxidant effects of flavonoids include the process of cleansing and neutralizing free radicals in the body. Free radicals are single electrons, unstable, and have a reactive effect [10]. Free radicals can cause endothelial cell damage. Endothelial cell damage is also associated with reduced absorption or production of NO (nitric oxide) as a vascular vasodilator [11]. According to research by Nugroho et al. (2012), phenol and flavonoid compounds with their antioxidant properties can prevent endothelial dysfunction in producing NO from the endothelium [12]. This nitric oxide can relax the vascular smooth muscle by activating guanylate cyclase to form cGMP (cyclic guanylate monophosphate), which will cause vasodilation [13]. This vasodilating effect will cause a decrease in blood pressure.

Tannins can also play a role in lowering blood pressure. According to research Lin et al. (2008), the antioxidant effect of geraniin, which is a class of tannin compounds, can show antihypertensive activity with antioxidant properties that can inhibit the performance of Angiotensin-Converting Enzyme (ACE) so that it can reduce systolic blood pressure and diastolic blood pressure [14]. Flavonoids can also act as a diuretic. Diuretics effectively lower blood pressure by reducing excess fluid volume and can reduce the heart's workload [15]. The mechanism of action of flavonoids works by increasing the glomerular velocity and inhibiting the reabsorption of $\mathrm{Na}^{+}, \mathrm{K}^{+}$, and $\mathrm{Cl}^{-}$, causing an increase in $\mathrm{Na}^{+}$and water in the tubules and an increase in urine volume. It causes a decrease in blood volume resulting in a decrease in blood pressure [16].

\section{Conclusion}

The results of research that have been carried out on qualitative, quantitative analysis and the effect of the Indonesia traditional medicinal herbs on reducing blood pressure in white male rats can be concluded as follows:

1. Indonesian traditional medicinal ingredients contain flavonoid compounds, phenols, tannins, and carbohydrates.

2. Indonesian traditional medicinal ingredients contain total flavonoid content of $0.6375 \%$, total phenol content of $3.2412 \%$, and total tannin content of $0.6593 \%$.

3. Indonesian traditional medicinal herbs provide lowering systolic blood pressure, diastolic, and arterial pressure. 


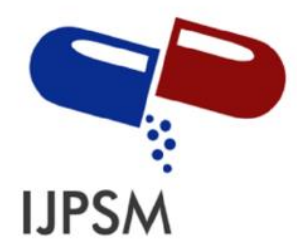

Oryza Sativa Fitriani et al, International Journal of Pharmaceutical Sciences and Medicine (IJPSM), Vol.6 Issue. 7, July- 2021, pg. 50-60

ISSN: 2519-9889

Impact Factor: 3.426

\section{Acknowledgement}

The researcher would like to thank the Dean of the Faculty of Pharmacy, Andalas University, who has permitted to research and use the equipment at the Pharmacology Laboratory, Faculty of Pharmacy, Andalas University, Padang.

\section{References}

[1]. Howland RD, Mycek MJ, Harvey RA, Champe PC. Lippincott's illustrated reviews: Pharmacology. Philadelphia: Lippincott Williams \& Wilkins; 2006.

[2]. Sukandar EY, Andrajati R, Sigit JI, Adnyana IK, Setiadi AP, Kusnandar. Iso Pharmacotherapy. Jakarta: PT ISFI Publishing; 2008.

[3]. Brunton LL, Chabner B, Knollmann BC, editors. Goodman \& Gilman's the pharmacological basis of therapeutics. New York, NY, USA: McGraw-Hill Education; 2018.

[4]. Pourjabali M, Mohammadrezaei-Khorramabadi R, Abbaszadeh S, Naghdi N, Naji-Haddadi S, Bahmani F. Medicinal plants used for hypertension. Journal of Pharmaceutical Sciences and Research. 2017 May 1;9(5):537.

[5]. Indonesia, Ministry of Health of the Republic. Indonesian Herbal Pharmacopoeia. Edition II. Jakarta: Indonesian Ministry of Health, 2017.

[6]. Vogel HG, Maas J, Gebauer A, editors. Drug discovery and evaluation: methods in clinical pharmacology. Springer Science \& Business Media; 2010 Dec 15.

[7]. Rumiyati R, Hakim AR, Winarti AD, Septia DN. Antihypertensive Testing of Combination of Apium Graveolans L., Orthosiphon Stamineus Benth., and Morinda Citrifolial Extract on Normotensive and Hypertensive Sprague Dawley Rats. Majalah Obat Tradisional. 2016;21(3):149-56.

[8]. Kowalak JP, Welsh W, Mayer B. Buku ajar patofisiologi. Jakarta: EGC. 2011;233.

[9]. Balasuriya BN, Rupasinghe HV. Plant flavonoids as inhibitors of angiotensin-converting enzymes in the regulation of hypertension. Functional foods in health and disease. 2011 May 8:1(5):172-88.

[10]. Lobo V, Patil A, Phatak A, Chandra N. Free radicals, antioxidants, and functional foods: Impact on human health. pharmacognostic review. 2010 July;4(8):118.

[11]. Wang Y, Mu JJ, Liu FQ, Ren KY, Xiao HY, Yang Z, Yuan ZY. Salt-induced epithelial-to-mesenchymal transition in Dahl salt-sensitive mice is dependent on the elevation of blood pressure. Brazilian Journal of Medical and Biological Research. 2014 March 18;47:223-30

[12]. Nugroho AE, Malik A, Pramono S. Total phenolic and flavonoid contents, and in vitro antihypertension activity of purified extract of Indonesian cashew leaves (Anacardium occidentale L.). International food research journal. 2013 Jan $1 ; 20(1)$.

[13]. McNeill JR, Jurgens TM. A systematic review of mechanisms by which natural products of plant origin evoke vasodilatation. Canadian Journal of physiology and pharmacology. 2006 Aug;84(8-9):803-21.

[14]. Lin SY, Wang CC, Lu YL, Wu WC, Hou WC. Antioxidant, anti-semicarbazide-sensitive amine oxidase, and antihypertensive activity of geraniin isolated from Phyllanthus urinaria. Food Toxicology and Chemistry. 2008 July 1;46(7):2485-92.

[15]. Muthia, Rahmi, et al. In vivo activity test of watermelon rind ethanol extract (Citrullus lanatus L.) as a diuretic with furosemide as a comparison. Borneo Journal of Pharmascientech, 2017, 1.1.

[16]. Howland RD, Mycek MJ, Harvey RA, Champe PC. Lippincott's illustrated reviews: Pharmacology. Philadelphia: Lippincott Williams \& Wilkins; 2006. 


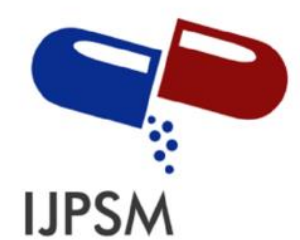

Oryza Sativa Fitriani et al, International Journal of Pharmaceutical Sciences and Medicine (IJPSM), Vol.6 Issue. 7, July- 2021, pg. 50-60

ISSN: 2519-9889

Impact Factor: 3.426

\section{A Brief Author Biography}

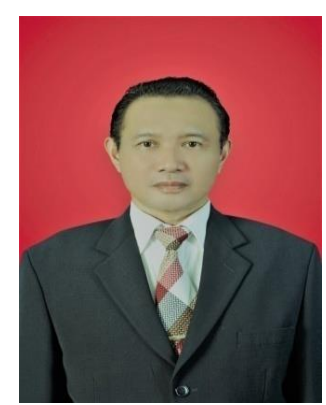

Prof. DR. Harrizul Rivai, M.S was born in Payakumbuh, West Sumatra, on 4 September 1953. His father is Rivai Said, and his mother is Saridahanum Syofyan. The Author obtained a Bachelor of Pharmacy from the Department of Pharmacy, Faculty of Mathematics and Natural Sciences, Padjajaran University, Bandung (1976), a Master of Science degree from the Bandung Institute of Technology (1984), and a Doctorate from the Department of Chemistry, Faculty of Mathematics and Natural Sciences, Andalas University, Padang (2011). Now the Author is a Professor and Researcher at the Faculty of Pharmacy, Andalas University, Padang. The Author also serves as Deputy Chair of Academic Affairs at the YPTIK Padang College of Pharmacy (STIFARM). The Author wrote the book "Principles of Chemical Examination" (Publisher UI-Press, 1995), translated the book "Pharmaceutical Statistics" (EGC Medical Book Publishers, 2010), and wrote "Chapter 4" in the book "Recent Research Advances in Biology Vol. 4" (Book Publisher International, India, and United Kingdom, 2020), and wrote the book "Chinese Petai (Leucaena leucocephala): Traditional Uses, Phytochemicals, and Pharmacological Activities" (Deepublish, Yogyakarta, 2021). He wrote "Chapter 9" in the book "Recent Research Advances in Biology Vol. 7" and "Chapters 5, 6, 7, and 8" in the book "Technological Innovation in Pharmaceutical Research Vol. 3 (Book Publisher International, India, and United Kingdom, 2021). The Author has also written articles in various international journals in various science fields, such as chemistry, biology, and pharmacy. 